Artykuly / Articles

\author{
Sylwia Zakrzewska \\ ORCID: 0000-0001-6010-7027 \\ sylwia.zakrzewska@uph.edu.p1 \\ Uniwersytet Przyrodniczo-Humanistyczny w Siedlcach \\ Wydział Nauk Społecznych
}

\title{
Kierunki doskonalenia systemu zarządzania kryzysowego w kontekście ochrony ludności i ratownictwa
}

\author{
Directions for Improving the Crisis Management System \\ in the Context of Population Protection and Rescue
}

DOI: $10.34739 /$ doc.2021.18.14

\begin{abstract}
Abstrakt: Artykuł dotyczy kwestii ochrony ludności i ratownictwa, realizowanego w ramach systemu zarzadzania kryzysowego. Stanowi on najważniejszy w Polsce mechanizm, służący monitorowaniu potencjalnych zagrożeń, przygotowaniu do skutecznej prewencji przed ich wystapieniem oraz sprawnego i wszechstronnego reagowania w razie wystapienia sytuacji kryzysowej, a także kompleksowego usuwania skutków zdarzeń nadzwyczajnych. Realizacja wskazanych zadan systemu sprowadza się przede wszystkim do pośrednich i bezpośrednich form ochrony ludności i ratownictwa, jak również ograniczenia wtórnych skutków zdarzeń kryzysowych dla ludności, mienia i środowiska. Niniejsze opracowanie prezentuje funkcjonowanie systemów ochrony ludności i ratownictwa oraz zarządzania kryzysowego w praktyce. Stanowi odniesienie do aspektów prawnych, organizacyjnych, planowania, finansowania działalności, a także stanu kadrowego i zaplecza materiałowo-technicznego, jakim one dysponuja. Wskazuje braki i potrzeby, występujące w ramach działania systemów, a także określa dalsze, proponowane kierunki badań i rozwoju systemów.
\end{abstract}

Słowa kluczowe: doskonalenie systemu zarządzania kryzysowego, ochrona ludności, ratownictwo, zarządzanie kryzysowe

Abstract: The subject of this study is civil protection and rescue implemented as part of the crisis management system which is the most important mechanism in Poland to monitor potential threats, prepare for effective prevention against their occurrence and efficient and comprehensive response in the event of a crisis, as well as comprehensive removing the effects of extraordinary events. The implementation of the indicated tasks of the system boils down mainly to direct and indirect forms of civil protection and rescue, as well as limiting the secondary effects of crisis for the population, property and the 
environment. This study presents the functioning of civil protection and rescue as well as crisis management systems in practice. It is a reference to the legal and organizational aspects, planning, financing of activities, as well as the human resources and material and technical facilities they have at their disposal. It indicates the gaps and needs occurring in the operation of systems and it also defines further directions proposed for research and development of systems.

Keywords: improvement of the crisis management system, civil protection, rescue, crisis management

\section{Wstęp}

Przedmiotem niniejszego opracowania sa dysfunkcje systemu zarządzania kryzysowego głównie w aspekcie ochrony ludności i ratownictwa. Omówienia problemu dokonano w wymiarze prawnym, organizacyjnym, planistycznym, finansowania, potencjału ludzkiego, a także zaplecza materiałowo-technicznego, którym dysponuja wiodace podmioty ratownictwa w Polsce. Zasadniczym celem artykułu jest wskazanie istniejacych braków, wad, a nawet sprzeczności, zachodzacych pomiędzy funkcjonujacym systemem zarzadzania kryzysowego a realnymi potrzebami i stawianymi przed nim oczekiwaniami. Krytyczne podłoże rozważań stanowiły wywiady eksperckie przeprowadzone $z$ przedstawicielami podmiotów wykonawczych zarządzania kryzysowego oraz administracji publicznej szczebla gminnego, powiatowego i wojewódzkiego. $Z$ racji ujednolicenia funkcjonowania systemu zarzadzania kryzysowego na obszarze całego kraju, jego działanie omówiono w oparciu o rozwiąania obowiąujace $\mathrm{w}$ województwie mazowieckim. Podsumowaniem rozważań są wnioski, zawierające propozycje rozwiązań i doskonalenia systemu zarządzania kryzysowego w kontekście ochrony ludności i ratownictwa.

\section{Wymiar prawny}

Pierwsze próby prawnego uregulowania problematyki dotyczącej ochrony ludności w Polsce uruchomiono po I wojnie światowej, powołujac organizacje obrony przeciwlotniczej i przeciwgazowej, które przygotowywały społeczeństwo do samoobrony na wypadek ataku nieprzyjaciela, a także uchwalajac jedną $z$ pierw- 
szych na świecie ustaw, dotyczących przedmiotowej problematyki ${ }^{1}$ Jednak pomimo świadomości ówczesnych władz o dużym znaczeniu tych zagadnień, realne kroki umożliwiające wdrożenie ustawowych zapisów podjęto dopiero 3 lata później, czyli dwa i pół roku przed wybuchem II wojny światowej². Mimo iż od wspomnianych wydarzeń minęło ponad 80 lat, niewiele zmieniło się $\mathrm{w}$ aspekcie postrzegania i prawnego regulowania spraw zwiazanych $z$ ogólnie pojmowaną ochroną ludności. Przemiany, jakie dokonały się u schyłku XX wieku podyktowały konieczność dostosowania polskich rozwiązań do standardów zachodnioeuropejskich. Jak się okazało, był to proces zarówno skomplikowany i rozciagnięty w czasie, jak również błędnie realizowany.

Zakończenie pierwszego 20-lecia XXI wieku pozwala stwierdzić, że funkcjonuje w Polsce system, przygotowywany, organizowany i utrzymywany w celu ochrony ludności przed nadzwyczajnymi zagrożeniami czasu pokoju, jednak wciąż posiada liczne braki, niedoskonałości i potrzeby. Intensyfikacja prac nad jego stworzeniem miała miejsce po roku 1997, kiedy skutki powodzi stulecia obnażyły nieadekwatność istniejących rozwiązań i niewydolność struktur państwa w obliczu zagrożeń bezpieczeństwa obywateli czasu pokoju3 ${ }^{3}$. Dopiero po 10 latach od tych tragicznych wydarzeń powołano w Polsce system zarządzania kryzysowego, służaccy ochronie ludności, zwierząt, mienia, środowiska oraz infrastruktury. Poza ustawa o zarządzaniu kryzysowym ${ }^{4}$, stanowiąca podstawe jego istnienia, przedmiotowa problematykę reguluje szereg innych aktów prawnych. Wśród najistotniejszych, poza Konstytucja Rzeczypospolitej Polskiej z dnia 2 kwietnia 1997 r., należy wymienić ustawy regulujace funkcjonowanie administracji rządowej i samorządowej, służb, inspekcji, straży, organizacji pozarzą-

\footnotetext{
1 Ustawa $z$ dnia 15 marca 1934 r. o obronie przeciwlotniczej i przeciwgazowej, Dz.U. 1934, nr 80, poz. 742.

2 Rozporządzenie Rady Ministrów z dnia 29 stycznia 1937 roku o przygotowaniu w czasie pokoju obrony przeciwlotniczej i przeciwgazowej Państwa, Dz.U. 1937, nr 10, poz. 73.

3 M. Kopczewski, M. Tobolski, Funkcjonowanie Krajowego Systemu RatowniczoGaśniczego istotnym elementem Systemu Zarzadzania Kryzysowego Państwa, [w:] Zarzadzanie kryzysowe $w$ systemie bezpieczeństwa narodowego, red. G. Sobolewski, D. Majchrzak, Warszawa 2001, s. 293.

${ }_{4}^{4}$ Ustawa z dnia 26 kwietnia 2007 r. o zarządzaniu kryzysowym, Dz.U. 2007, nr 89, poz. 590 .
} 
dowych, zasady wprowadzania i obowiązywania stanów nadzwyczajnych, a także rozporządzenia regulujące szczegółowe aspekty bezpieczeństwa powszechnego.

Bez większych trudności wymienić można przeszło 40 aktów prawnych, regulujących w sposób bezpośredni omawiane zagadnienie $^{5}$. Doskonale obrazuje to stan, a zarazem zasady tworzenia polskiego prawa. Ustawodawcy nie widza potrzeby ujmowania poszczególnych sfer funkcjonowania państwa i jego obywateli w sposób kompleksowy, syntetyczny i jasno zdefiniowany. Zamiast tego, pojawiające się luki i potrzeby w zakresie legislacyjnym, uzupełniane sa kolejnymi szczegółowymi aktami prawnymi, które nie zawsze koresponduja $z$ obowiąującym prawem. W konsekwencji, uregulowania dotyczące zadań i struktur organizacyjnych podmiotów, odpowiedzialnych za szeroko rozumiana ochronę ludności rozproszone sa w wielu dokumentach normatywnych. Watpliwości nie pozostawia fakt, że problematyka ochrony ludności wymaga kompleksowego i jednolitego ujęcia w postaci jednego aktu prawnego.

Nie jest to odosobniona sugestia. Środowiska zajmujące się przedmiotowa problematyka od wielu lat postuluja potrzebę takiego rozwiązania. Już w 1995 r. powstał projekt ustawy o obronie cywilnej, gdyż obowiąujące akty prawne w tym zakresie już wówczas uznano za anachroniczne. Wyraźnie uwidocznił to największy w powojennej Polsce i Europie pożar lasu w Kuźni Raciborskiej, który wybuchł 26 sierpnia 1992 r., a więc tuż po zorganizowaniu Państwowej Straży Pożarnej (1 lipca 1992 r.). W kulminacyjnej fazie pożaru w akcji gaśniczej uczestniczyło 859 sekcji straży pożarnej (4700 strażaków, ponad 1000 wozów gaśniczych), 3200 żołnierzy, 650 policjantów, 1220 członków formacji obrony cywilnej, 1150 pracowników Służby Leśnej. Ogień zniszczył 9062 ha lasu. W płomieniach zginęło dwóch strażaków. Śmierć poniosła również potrącona przez wóz gaśniczy 23-letnia mieszkanka Rud ${ }^{6}$. Zdarzenie to obnażyło braki materiałowe, kompetencyjne oraz logistyczne służb ratunkowych. W najgorszej sytuacji była wówczas obrona cywilna, za która odpowiedzialność „przerzucano” między resortami spraw

\footnotetext{
5 Cf. P. Gromek, W sieci ratownictwa, Warszawa 2018, s. 131-178.

6 A. Król, A. Biernat, Pożar lasu w Kuźni Raciborskiej: Piekło sprzed 25 lat. Opowieści ludzi, którzy walczyli $z$ ogniem, www.plus.dziennikzachodni.pl/pozar-lasuw-kuzni-raciborskiej-pieklo-sprzed-25-lat-opowiesci-ludzi-ktorzy-walczyli-zogniem/ar/12396097 (data dostępu: 31.12.2020).
} 
wewnętrznych i obrony narodowej7. W konsekwencji tych posunięć członkowie formacji OC nie posiadali nawet stosownego wyposażenia i umundurowania, umożliwiającego im udział $\mathrm{w}$ tak niebezpiecznej akcji ratunkowej ${ }^{8}$.

Kolejne postulaty zmian prawnych powstały po roku 2000, równolegle $z$ projektowanym systemem zarządzania kryzysowego. Pierwszy projekt ustawy o krajowym systemie ratowniczym datowany jest na 27 maja 2003 r. Następna propozycja, również w randze ustawy, pochodzi z marca 2009 r. i dotyczy ochrony ludności. W dalszej kolejności zaprezentowano również projekt ustawy o ochronie ludzi i środowiska przed nadzwyczajnymi zagrożeniami ${ }^{9}$. Następny projekt ustawy o ochronie ludności i obronie cywilnej powstał w grudniu 2016 r. Zgodnie $z$ zapowiedzia sekretarza stanu w MSWiA miał on trafić do Sejmu z końcem 2016 r., jednak do końca 2019 r. nie znalazł się nawet w wykazie projektów ustaw, zamieszczonych na stronie Rządowego Centrum Legislacji. Zamiast niego 4 lipca 2019 r. powstał nowy projekt ustawy o ochronie ludności i obronie cywilnej. Przekazany został do Rządowego Centrum Legislacji pod numerem UD24 w wykazie prac legislacyjnych i programowych Rady Ministrów. Obecnie znajduje się w drugiej (uzgodnienia) z 14 faz procesu legislacyjnego, zaś ostatnia jego modyfikacja pochodzi $z 17$ czerwca $2020 \mathrm{r}^{10}$. Nowe, adekwatne do współczesnych potrzeb i zagrożeń, rozwiązanie prawno-systemowe jest niezaprzeczalnie koniecznym elementem budowania bezpieczeństwa powszechnego. Świadczą o tym również oceny Najwyższej Izby Kontroli, zawarte w informacji o wynikach kontroli przeprowadzonej w latach 2015-201711. Po 10 (od zakończenia kontroli), a nawet blisko 14 latach od utworzenia zarzadzania kryzysowego w Polsce, nadal nie funkcjonuje ono właściwie.

7 R. Kalinowski, Od gotowości cywilnej do zarzadzania kryzysowego, „Przegląd Naukowo-Metodyczny. Edukacja dla Bezpieczeństwa” 2013, nr 4, s. 97-120.

8 Wysoka temperatura ściółki leśnej powodowała topnienie obuwia, w które byli wyposażani członkowie formacji OC.

9 Cf. P. Szmitkowski, System ochrony ludności w Polsce - historia i współczesność, „Colloquium Wydziału Nauk Humanistycznych i Społecznych” 2012, nr 4, s. 133-156.

10 Projekt ustawy o ochronie ludności i obronie cywilnej, Rządowe Centrum Legislacji, www.legislacja.rcl.gov.pl/projekt/12322353 (data dostępu: 31.12.2020).

11 Najwyższa Izba Kontroli, Informacja o wynikach kontroli Ochrona ludności $w$ ramach zarzadzania kryzysowego $i$ obrony cywilnej, Warszawa 2019, KPB.430.009.2017, Nr ewid. 147/2018/P/1039/KPB. 
Zasadniczym mankamentem prawnym jest niejasna definicja sytuacji kryzysowej. Zgodnie $z$ litera prawa należy przez nia rozumieć sytuację wpływajacca negatywnie na poziom bezpieczeństwa ludzi, mienia w znacznych rozmiarach lub środowiska, wywołujaca znaczne ograniczenia w działaniu właściwych organów administracji publicznej ze względu na nieadekwatność posiadanych sił i środków. W ocenie organów administracji publicznej właściwych w sprawach zarządzania kryzysowego największe trudności w klasyfikowaniu sytuacji jako kryzysowej budzi interpretacja zapisów o nieadekwatności posiadanych sił i środków oraz o znacznych rozmiarach i znacznych ograniczeniach. Wattpliwości budzą także: poziom bezpieczeństwa ludzi oraz właściwe organy administracji. Zatem definicja, która w założeniu można byłoby uznać za nieco elastyczna, dajacca znaczne ułatwienie decydentom w postrzeganiu i reagowaniu na pojawiające się zagrożenia, stanowi w praktyce poważne utrudnienie. Tak nieostre ujęcie definicyjne kluczowego terminu, a zarazem przesłanki uruchomienia procedur zarzadzania kryzysowego wręcz uniemożliwia właściwe funkcjonowanie systemu. Zważywszy na fakt, iż organy kierujące muszą podejmować wielokrotnie natychmiastowe decyzje, pod presja czasu i w deficycie informacyjnym możliwość dowolnego rozumienia i oceny tego zapisu ustawowego stanowi istotny problem, zaś zaniechanie uruchomienia procedur zarzadzania kryzysowego generuje dodatkowe negatywne skutki zagrożenia. Nawet wnioskowanie przez wojewodę do Ministra Obrony Narodowej o użycie oddziałów lub pododdziałów Sił Zbrojnych RP w ocenie NIK ${ }^{12}$ oraz opinii organów administracji publicznej różnych szczebli nie może stanowić przesłanki do uznania sytuacji za kryzysowa.

Oczekiwania zmian w tym zakresie sa dalece złudne, zważywszy na fakt, iż kolejny rządowy projekt ustawy, tym razem o zmianie ustawy o zarządzaniu kryzysowym oraz niektórych innych ustaw, który wpłynał do Sejmu RP 29 stycznia 2020 r., nie rozwiazuje żadnego $z$ wcześniej nakreślonych problemów. Stanowi jedynie odpowiedź na postawione przez Unię Europejska cele oraz wymogi, wynikajace $z$ Unijnego Mechanizmu Ochrony Ludności w zakresie zarządzania kryzysowego. Przewiduje się w nim zatem m.in. wyod-

12 Ibidem, s. 56. 
rębnienie krajowej oraz lokalnej infrastruktury krytycznej, wprowadzenie instytucji koordynatora do spraw ochrony infrastruktury krytycznej u wszystkich operatorów tej infrastruktury, który będzie wyznaczany spośród pracowników operatora infrastruktury krytycznej. Również opracowywane do tej pory plany zarządzania kryzysowego zostana podzielone na: plany zarządzania ryzykiem odnoszące się do działań związanych $z$ zapobieganiem sytuacjom kryzysowym oraz przygotowywaniem do ich wystapienia oraz plany reagowania kryzysowego - dotyczace działań $z$ zakresu reagowania w przypadku wystapienia sytuacji kryzysowych oraz usuwaniu ich skutków. Ponadto cykl planistyczny zostaje wydłużony do lat trzech ${ }^{13}$, jednak w dalszym ciagu nie precyzuje się zakresu terminów „systematyczna aktualizacja” oraz „cykl planistyczny”. Natomiast kosmetyczna zmiana definicji sytuacji kryzysowej14, wciąż nie ułatwia podmiotom decyzyjnym kwalifikacji zdarzenia jako miejscowego zagrożenia bądź wspomnianej sytuacji kryzysowej15.

Przedmiotowe działanie nie pozostawia zatem złudzeń, iż jest jedynie wynikiem nowej perspektywy finansowej UE na lata 2021-2027, a co za tym idzie, możliwości pozyskiwania funduszy w ramach polityki spójności. W związku z powyższym nietrudno zauważyć, że tworzony od dziesięcioleci system ochrony ludności nadal nie funkcjonuje właściwie za sprawą licznych braków i niedoskonałości już w sferze prawnej, stanowiącej podstawe jego istnienia. Nie można zatem oczekiwać prawidłowego funkcjonowania struktur organizacyjnych i właściwej realizacji procedur, jeśli nie mają one stosownego uzasadnienia prawnego. Pamiętać należy, że nawet najlepiej wyposażone i wyszkolone służby o najwyższym stopniu zaangażowania nie sa $\mathrm{w}$ stanie efektywnie działać i ratować poszkodowanych bez stosownej organizacji, osadzenia $\mathrm{w}$ ramach

13 Rzadowy projekt ustawy o zmianie ustawy o zarzadzaniu kryzysowym oraz niektórych innych ustaw, www.sejm.gov.pl/Sejm9.nsf/PrzebiegProc.xsp?nr=203 (31.12.2020).

${ }_{14}$ Zgodnie $z$ projektem ustawy o zarzadzaniu kryzysowym oraz niektórych innych ustaw, przez sytuację kryzysowa należy rozumieć: „sytuację wpływająca negatywnie na poziom bezpieczeństwa ludzi, mienia w znacznych rozmiarach, środowiska lub dziedzictwa kulturowego, wywołujaca znaczne ograniczenia w działaniu właściwych organów administracji publicznej ze względu na nieadekwatność posiadanych sił i środków lub zakłócenia obsługi tych organów". Ibidem.

15 Ostatnie prace nad projektem ustawy miały miejsce 3 czerwca 2020 r. Zakończyły się przyjęciem projektu $z$ poprawkami przez Komisję Administracji i Spraw Wewnętrznych (stan na 31.12.2020). 
prawnych i kompetencyjnych, zapewniajacych dobra koordynację i kierowanie działaniami ratowniczymi.

\section{Struktury organizacyjne}

Poza scharakteryzowanym powyżej aspektem prawnym, równie istotnym wymiarem funkcjonowania zarządzania kryzysowego sa jego struktury organizacyjne. Niestety ich przygotowanie, kompetencje, a w niektórych przypadkach nawet brak istnienia ${ }^{16}$, wręcz uniemożliwiają właściwe działanie systemu zarządzania kryzysowego. Istotne zastrzeżenia, dotyczace niewłaściwego funkcjonowania zarządzania kryzysowego, związane sa ze strukturami administracji rządowej i samorządowej. Na szczeblu wojewódzkim organizacja systemu przedstawia się najlepiej. W urzędach wojewódzkich funkcjonują komórki właściwe w sprawach zarządzania kryzysowego. Powołane zostały także Centra Zarządzania Kryzysowego, zapewniające całodobowy dyżur, obieg informacji i monitorowanie zagrożeń. Problemem zgłaszanym przez pracowników tych jednostek jest częsty brak dwuosobowej służby dyżurnej. Kontrole NIK wykazały również brak bezpośredniej komunikacji między CZK poszczególnych województw, a także stosowanie nieefektywnych sposobów powiadamiania podmiotów ujętych w siatce bezpieczeństwa o sytuacjach kryzysowych. Natomiast ze strony technicznej poważnym problemem jest brak awaryjnego zasilania centrów, co w sytuacji braku dostępu do energii elektrycznej uniemożliwia ich funkcjonowanie $^{17}$.

Znacznie gorzej sytuacja przedstawia się na niższych poziomach administracyjnych. Tutaj zastrzeżenia NIK dotycza nie tylko względów organizacyjnych, lecz również kwalifikacji merytorycznych pracowników odpowiedzialnych za zarządzanie kryzysowe na szczeblu powiatu i gminy. Przeprowadzone kontrole wykazały, że mimo ustawowego obowiązku nadal występuja powiaty, w których

\footnotetext{
16 Wyniki kontroli NIK wskazuja, że w powiecie chojnickim Powiatowe Centrum Zarzązania Kryzysowego zostało utworzone 29 września 2017 r., czyli po 10 latach od wejścia w życie Ustawy z dnia 26 kwietnia 2007 r. o zarządzaniu kryzysowym. Najwyższa Izba Kontroli, Informacja o wynikach... .

17 Ibidem. Cf. R. Kalinowski, Wybrane problemy zarzadzania kryzysowego na szczeblu województwa. Wstępne refleksje $z$ badan, [w:] Elementy teorii $i$ praktyki transdyscyplinarnych badań problemów bezpieczeństwa, T. III, Psychospołeczne i organizacyjne aspekty zarzadzania kryzysowego, red. A.W. Świderski, Siedlce 2014.
} 
nie został zapewniony całodobowy dyżur pełniony w ramach Centrów Zarządzania Kryzysowego. Przygotowanie struktur administracji na szczeblu gminnym ocenione zostało najgorzej w skali całego kraju. Zasadniczym i powszechnym problemem występujacym na tym poziomie jest marginalizowanie rangi zarzadzania kryzysowego, obrony cywilnej i ogólnie pojmowanej ochrony ludności, przejawiajacce się w powierzeniu jednej osobie odpowiedzialności za realizacje spraw związanych $z$ bezpieczeństwem ludności, zarządzaniem kryzysowym, obrona cywilna jedynie w ramach części etatu, którego uzupełnienie stanowią zadania $z$ zakresu ochrony informacji niejawnych, spraw obywatelskich czy nawet księgowości budżetowej. Przedstawiony stan rzeczy nawet w ujęciu teoretycznym czyni stan przygotowań i realizacji przedsięwzięć z zakresu zarządzania kryzysowego nierealnym ${ }^{18}$.

Dodatkowym elementem potęgującym ten negatywny stan przygotowań struktur gminnych jest niepowołanie nawet gminnych zespołów zarządzania kryzysowego, pomimo ustawowego obowiąku. Zaniedbanie to powoduje $z$ kolei niemożność zapewnienia całodobowego dyżuru na obszarze gmin, co w konsekwencji sprawia, że funkcjonowanie zarządzania kryzysowego na danym obszarze jest organizacyjnie niemożliwe. Zważywszy dodatkowo na brak właściwego przygotowania merytorycznego pracowników odpowiedzialnych za przedmiotowa problematykę, choćby ze względu na wypełnianie zbyt dużej ilości niezwiąanych ze sobą obowiązków, nie można mówić o funkcjonowaniu zarządzania kryzysowego w tych jednostkach administracyjnych.

Zauważyć również należy, że na wszystkich organach właściwych w sprawach zarządzania kryzysowego ciąży ustawowy obowiązek organizacji ćwiczeń i szkoleń z zakresu przedmiotowej problematyki. Jednak był on realizowany niezwykle rzadko. Struktury administracji samorządowej uczestniczyły głównie w przedsięwzięciach tego rodzaju organizowanych na szczeblu wojewódzkim, rezygnując $z$ ich realizacji przeznaczonej dla podległych im jednostek. Zaprezentowany stan rzeczy nie pozostawia watpliwości, że pozostałe aspekty zarządzania kryzysowego moga funkcjonować prawidłowo. W obliczu tak poważnych zaniedbań organizacyjnych wła-

\footnotetext{
18 Najwyższa Izba Kontroli, Informacja o wynikach... .
} 
ściwy przepływ informacji czy proces powiadamiania o zagrożeniach struktur i służb włączonych do systemu jest już $z$ założenia nierealny. Generuje to $z$ kolei brak odpowiedniego ostrzegania i alarmowania ludności o zagrożeniach, wydawania komunikatów zawierających zalecenia i procedury postępowania dla ludności, znajdującej się na obszarach występowania bądź prognozowanego zaistnienia zagrożenia.

\section{Planowanie}

W ustawie $z$ dnia 26 kwietnia 2007 roku o zarzadzaniu kryzysowym ${ }^{19}$ ustawodawca poświęca wiele uwagi planom zarządzania kryzysowego, ich strukturze oraz procedurom opracowywania i aktualizacji. Wnioskować zatem należy, że dokumenty te stanowia istotna podstawę organizacji i funkcjonowania całego systemu. Sa funkcjonalnym narzędziem zarządzania, kierowania i koordynacji przedsięwzięć ratowniczych. Rzetelnie przygotowane dokumenty planistyczne, zapewniaja spójność realizacji faz zarządzania kryzysowego zarówno w układzie pionowym, jak i poziomym, a także wdrażanie optymalnych procedur reagowania, dysponowania sił i środków oraz zharmonizowane ich działanie. Istotna rolę w zapewnianiu spójności planów zarządzania kryzysowego na poszczególnych szczeblach administracyjnych odgrywaja wytyczne i zalecenia do ich opracowywania, sporządzane przez organ wyższego szczebla i przekazywane bezpośrednio podległemu organowi właściwemu w sprawach zarządzania kryzysowego. Umożliwiaja one również wpływ organów wyższego szczebla na przygotowanie i realizację zarządzania kryzysowego na obszarach jednostek terytorialnych im podległych.

Wyniki kontroli przeprowadzonych przez Najwyższą Izbę Kontroli 20 dowodza, że $\mathrm{w}$ tym aspekcie funkcjonowania zarządzania kryzysowego również występuja poważne uchybienia. Świadczy to o poważnym niezrozumieniu przez podmioty odpowiedzialne za ochronę ludności w ramach zarządzania kryzysowego zapisów ustawowych, a także przeznaczenia i rangi dokumentów planistycznych. Nagminnym błędem popełnianym przez osoby sporządzajace plany i ich aktualizacje jest bagatelizowanie ich rangi, prze-

19 Ustawa $z$ dnia 26 kwietnia 2007 r. o zarządzaniu... .

20 Najwyższa Izba Kontroli, Informacja o wynikach..., s. 12, 35-50. 
jawiające się w dublowaniu treści zawartych w planach zarządzania kryzysowego wyższych szczebli administracji. Zabieg ten sprawia, że dokumenty te sa nieadekwatne do realiów danej jednostki organizacyjnej i nie identyfikuja jej rzeczywistych potrzeb w obliczu sytuacji kryzysowych. Nie ma zatem możliwości funkcjonalnego wykorzystania siatki bezpieczeństwa, wdrożenia procedur alarmowania członków zespołu zarządzania kryzysowego, dysponowania i łączności z podmiotami wykonawczymi, a także ostrzegania i powiadamiania zagrożonej ludności. Zdarzaja się nawet przypadki uznawania za aktualny i obowiazujący plan reagowania kryzysowego opracowany na podstawie zapisów ustawy z dnia 26 kwietnia 2007 r. o zarzadzaniu kryzysowym w brzmieniu przed nowelizacja uchwalona w 2009 r. ${ }^{21}$, bądź zmiany nazwy na plan zarządzania kryzysowego w drodze aktualizacji bez wprowadzania jakichkolwiek korekt merytorycznych w jego treści na przełomie 9 lat.

Treść wspomnianych wyżej wytycznych i zaleceń do planów zarządzania kryzysowego również nie została jasno zdefiniowana ustawowo. Organy właściwe w sprawach zarządzania kryzysowego maja dzięki temu możliwość indywidualnego wpływu na ich zakres, a tym samym pewna kontrolę działalności planistycznej, realizowanej na obszarach im podległych. W praktyce doszło jednak do ponownego niezrozumienia intencji ustawodawcy. Wojewodowie i starości realnie nie egzekwuja opracowania planów zarządzania kryzysowego w oparciu o wydawane przez nich wytyczne/zalecenia, mimo iż zgodnie $z$ ustawa o zarzadzaniu kryzysowym maja one wiażacy charakter. Dokonuja często wręcz automatycznego zatwierdzenia planów zarządzania kryzysowego wpływających $z$ niższych szczebli bez ich kontroli i znajomości treści. Dodatkowo samo opracowywanie wytycznych i zaleceń postrzegaja w kategoriach ustawowego obowiazku, a nie możliwości współtworzenia zarządzania kryzysowego w samorządach. Stąd ich treść również najczęściej bywa dublowana $z$ naniesieniem jedynie stosownego nazewnictwa.

Występuja też przypadki zaniechania opracowania planów zarządzania kryzysowego mimo wydania do nich wytycznych przez

21 Od 2008 r. do 5 września 2017 r. w gminie Stare Miasto obowiazywał plan reagowania kryzysowego. Sporzadzone w 2011 i 2016 r. projekty planu zarzadzania kryzysowego do 2017 r. nie były przekazane staroście w celu zatwierdzenia. Najwyższa Izba Kontroli, Informacja o wynikach... 
organ nadrzędny. Kontrole NIK wykazały brak rzetelności podczas analizowania zagrożeń, opracowywania planów, uzgadniania ich $\mathrm{z}$ kierownikami jednostek organizacyjnych w zakresie współdziałania, a także opiniowania przez zespoły zarządzania kryzysowego i zatwierdzania przez organy nadrzędne. Nieprawidłowości dotycza nawet braku spójności pomiędzy poszczególnymi elementami danego planu. Zdarza się, że zagrożenia opisane w „charakterystyce zagrożeń” jako zdarzenia generujące poważne sytuacje kryzysowe, nie miały żadnego odniesienia w „siatce bezpieczeństwa” lub zagrożenia typowe dla danego obszaru nie zostały w ogóle zidentyfikowane i ujęte w planie 22 .

Na podstawie przytoczonych uchybień, zaniedbań i błędów merytoryczno-formalnych wnioskować należy, że sporządzanie planu zarzadzania kryzysowego jest jedynie przymusowym wypełnieniem ustawowego obowiazku, a nie funkcjonalnym narzędziem podczas zarzadzania sytuacja kryzysowa. W konsekwencji większość obowiązujących planów zarządzania kryzysowego jest niezgodna $z$ wytycznymi i zaleceniami organów nadrzędnych właściwych w sprawach zarządzania kryzysowego, obarczona licznymi błędami merytorycznymi, nieaktualna i nie spełnia wymogów ustawy o zarządzaniu kryzysowym. W opinii organów administracji publicznej brakuje narzędzi prawnych, służących egzekwowaniu zgodności planów zarzadzania kryzysowego $z$ przekazywanymi wytycznymi/zaleceniami, a sama ustawa nie stanowi jednoznacznych podstaw do nadzoru nad wdrożeniem poleceń. Nie istnieje zatem jakiekolwiek prawdopodobieństwo, że gminne, powiatowe i wojewódzkie plany zarządzania kryzysowego sa spójne i koresponduja ze soba, choćby w obrębie województwa. Świadczy o tym nawet fakt nieinformowania odpowiednich organów zarządzania kryzysowego wyższych szczebli przez kierowników jednostek właściwych w sprawach zarządzania kryzysowego o wprowadzonych modyfikacjach do planów zarządzania kryzysowego, dokonywanych pomiędzy zatwierdzaniem kolejnych planów. Na podstawie istotności i skali ujawnionych nieprawidłowości wnioskować należy, że problematyka ochrony ludności w postrzeganiu organów administracji publicznej ustawowo zobowiąanych do jej realizacji nie stanowi obszaru znaczącego dla funkcjonowania państwa.

22 Ibidem. 


\section{Finansowanie, potencjal ludzki}

\section{i zaplecze materiałowo-techniczne}

Finansowanie funkcjonowania systemu zarządzania kryzysowego niewatpliwie najbardziej widoczne jest w sferze wykonawczej. Środki przeznaczane na ten cel jasno obrazuja stan osobowy służb oraz podmiotów ratowniczych, a także ich wyposażenie. W mniejszym stopniu przekłada się ono na jakość funkcjonowania sfery kierowniczo-organizacyjnej, chociaż w tym obszarze również można wskazać istotne zależności. Niedostateczne nakłady finansowe generuja niskie pensje pracowników administracji, którym powierzono odpowiedzialność za realizację zarządzania kryzysowego na danym obszarze. Stanowiska pracy staja się tym samym nieatrakcyjne dla wykwalifikowanych specjalistów w przedmiotowym zakresie. Wakaty obsadzane sa zatem pracownikami pozbawionymi stosownego przygotowania merytorycznego, umożliwiającego właściwa realizację powierzonych obowiąków. Dodatkowo brakuje środków finansowych na ich szkolenie. Zgłaszanie konieczności udziału w zajęciach teoretyczno-praktycznych, dotyczacych funkcjonowania i obsługi skomplikowanych systemów informatycznych, monitorujacych zagrożenia lub umożliwiających symulację zdarzeń, prognozowanie ich rozwoju i zarządzanie nimi ze stanowiska kierowania podczas organizowania i prowadzenia ćwiczeń oraz szkoleń nie było odosobnione. W tej sytuacji tworzenie i wdrażanie zaawansowanych systemów informatycznych nie wydaje się mieć uzasadnienia, zważywszy, że podmioty dla których sa one dedykowane nie posiadaja kompetencji i wiedzy merytorycznej, pozwalającej na ich obsługę i wykorzystanie.

Natomiast stan osobowy i wyposażenie wspomnianych wyżej służb i podmiotów ratowniczych, w przeciwieństwie do jednostek administracyjnych, jest ściśle uzależnione od nakładów finansowych przeznaczanych na ten cel. Najlepszym odzwierciedleniem tego stanu jest sytuacja Państwowego Ratownictwa Medycznego, które wspólnie $z$ jednostkami straży pożarnej stanowi zasadniczy podmiot wykonawczy zarządzania kryzysowego i jednocześnie podstawowa służbę ochrony ludzkiego zdrowia i życia w zdarzeniach dnia codziennego.

Mimo optymistycznego wzrostu w ciagu ostatnich trzech lat liczby Zespołów Ratownictwa Medycznego na terenie województwa mazowieckiego ze 187 w 2015 r. do 201 w 2021 r., Plan działania 
systemu Państwowe Ratownictwo Medyczne dla Województwa Mazowieckiego, uwzględnia likwidację dyspozytorni medycznej w Grodzisku Mazowieckim. Od 1 kwietnia 2019 r. funkcjonuje zatem 5 dyspozytorni oraz 5 Rejonów Operacyjnych na Mazowszu. Dostosowanie jednak stanu realnego do wymogów ustawowych ${ }^{23}$, obowiazujących od 1 stycznia 2021 r., oznacza likwidację kolejnych 3 dyspozytorni. W zwiąku $z$ powyższym od 1 kwietnia 2021 r., na terenie województwa mazowieckiego będa funkcjonowały 3 rejony operacyjne, zlokalizowane w Warszawie, Siedlcach i Radomiu ${ }^{24}$.

W skład wspomnianych wcześniej 201 Zespołów Ratownictwa Medycznego (ZRM) wchodzi 39 (51 w 2018 r.) specjalistycznych oraz 162 (145 w 2018 r.) podstawowych zespołów, z czego 16 (bez zmian względem 2018 r.) podstawowych ZRM funkcjonuje w trybie 12-godzinnym, zaś w Rejonie Operacyjnym 14/01 (Warszawa) funkcjonuje 1 wodny ZRM. Po 1 kwietnia 2021 r. dane te pozostać maja niezmienione. Działalność ZRM wspierana jest przez Lotnicze Pogotowie Ratunkowe (LPR), stacjonujace w Warszawie, Płocku i Sokołowie Podlaskim. Obecnie działalność 5 dyspozytorni medycznych zabezpieczaja 34 stanowiska dyspozytorskie, w tym 9 stanowisk dyspozytorów wysyłajacych i 20 stanowisk dyspozytorów przyjmujących oraz 5 stanowisk Głównego Dyspozytora Medycznego. Od 1 kwietnia 2021 r. funkcjonować będą 3 dyspozytornie medyczne z 31 stanowiskami dyspozytorskimi, przy czym $8 \mathrm{z}$ nich to stanowiska dyspozytorów wysyłających, zaś 20 - stanowiska dyspozytorów przyjmujących oraz 3 stanowiska Głównego Dyspozytora Medycznego ${ }^{25}$.

Na wypadek zaistnienia zdarzeń o charakterze nadzwyczajnym przewiduje się możliwość uruchomienia dodatkowych ZRM. $\mathrm{W}$ praktyce rozwiazanie to jest bardzo często wykorzystywane. $Z$ uwagi na zalecenia Ministra Zdrowia, dotyczące utrzymywania

\footnotetext{
23 Ustawa $z$ dnia 8 września 2006 r. o Państwowym Ratownictwie Medycznym, Dz.U. 2006, nr 191, poz. 1410. Zgodnie $z$ art. 25a ust. 1 i 2 wojewoda tworzy i prowadzi jedna dyspozytornię medyczna w województwie. W województwie mazowieckim oraz $\mathrm{w}$ województwie śląskim wojewodowie moga utworzyć i prowadzić dwie dyspozytornie medyczne.

24 Mazowiecki Urząd Wojewódzki w Warszawie, Plan działania systemu PRM, www.gov.pl/web/uw-mazowiecki/plan-dzialania-systemu-prm (data dostępu: 31.12.2020).

25 Plan działania systemu Państwowe Ratownictwo Medyczne dla województwa mazowieckiego, Tekst jednolity, Warszawa 18.12.2020 r., s. 8, 12-13, 20.
} 
1 ZRM przypadającego na 33 tys. mieszkańców w zdarzeniach dnia codziennego często dochodzi do deficytu zespołów ratunkowych, zaś co rok liczba zdarzeń wzrasta o $2-3 \%$. Potrzeby ratownicze sa w miarę możliwości wspierane przez LPR, jednak gdy właściwości terenu uniemożliwiaja jego udział pozostaje ewentualność dysponowania wolnych zespołów powiatowych bądź zastosowanie priorytetów medycznych ${ }^{26}$.

Sytuacja pozostałych służb wykonawczych zarzadzania kryzysowego przedstawia się znacznie lepiej. Państwowa i Ochotnicza Straż Pożarna posiada nowoczesny, specjalistyczny sprzęt, dwie Komendy $z$ Mazowieckiego Garnizonu Policji wyposażone zostały $\mathrm{w}$ dron, służący poszukiwaniu zaginionych osób, również wojsko jest systematycznie rozwijane i doposażane w wielozadaniowy sprzęt. Jednak posiadane obecnie siły i środki służb odpowiedzialnych w sposób pośredni i bezpośredni za ochronę ludności są odpowiednie do reagowania na typowe i doraźne zdarzenia lokalne. W przypadku konieczności prowadzenia akcji długofalowych, posiadany sprzęt jest niewystarczający. Wsparcie udzielone przez organizacje pozarzadowe, statutowo zobligowane do udzielania pomocy poszkodowanym, również może okazać się nieadekwatne do potrzeb $z$ racji znacznych zaniedbań $w$ ich finansowaniu i wyposażaniu w niezbędny sprzęt ratunkowy. Brakuje także umów i porozumień zawieranych $z$ lokalnymi przedsiębiorcami, dysponujacymi specjalistycznym wyposażeniem, które w obliczu zagrożeń nadzwyczajnych, deficytu sił i środków, mogłoby przesądzić o skuteczności realizowanych działań ratowniczych ${ }^{27}$.

\section{Wnioski}

W oparciu o dokonane rozważania stwierdzić należy, że istnieje pilna potrzeba zmian prawnych, majacych na celu budowę kompleksowego, sprawnego, zintegrowanego oraz funkcjonalnego systemu zarządzania kryzysowego i ochrony ludności. Konieczne jest podjęcie niezwłocznych działań, zmierzających do kompleksowego uregulowania prawnego problematyki ochrony ludności i w konse-

26 Dariusz Szpakowski, dyrektor RM-Meditrans w Siedlcach, relacja ustna zanotowana przez autorkę 11.12.2018.

27 Dane pozyskane $\mathrm{w}$ trakcie wywiadów przeprowadzonych $\mathrm{z}$ dowódcami właściwych jednostek organizacyjnych Państwowej Straży Pożarnej, Policji, Wojskowej Komendy Uzupełnień w Siedlcach w grudniu 2018 r. 
kwencji stworzenia jednolitego aktu prawnego, określającego rolę i zadania struktur odpowiedzialnych za zarządzania kryzysowe, ochronę ludności i obronę cywilna, a także kompetencje poszczególnych służb wykonawczych i zachodzacych między nimi relacji.

Należy również naprawić wiele błędów i niejasności definicyjnych zawartych w ustawie o zarządzaniu kryzysowym. Konieczne jest jednoznaczne zdefiniowanie sytuacji kryzysowej, w taki sposób, aby organy administracji, podejmujące kierowanie akcja ratunkowa pod presją czasu nie miały wątpliwości, z czym maja do czynienia (miejscowym zagrożeniem czy sytuacja kryzysowa). Doprecyzowania i konkretnego określenia terminów przeznaczonych na opracowanie wymaga Raport o zagrożeniach bezpieczeństwa narodowego, którego wnioski mają stanowić element Krajowego Planu Zarządzania Kryzysowego oraz aktualizacje planów zarządzania kryzysowego. Zabieg ten umożliwi wykluczenie sporządzania planu w oparciu o projekt Raportu, mogącego ulec zmianom. Należy również jasno wskazać czy wytyczne i zalecenia do planów ZK maja podlegać również dwuletniej aktualizacji i kiedy maja być opracowywane, aby zachować dwuletni cykl planowania, umożliwiający aktualizację planów w tych ramach czasowych. Zauważyć również należy, że żaden $z$ przepisów prawa nie określa, jaki powinien być zakres aktualizacji planu ani nie przewiduje odrębnych procedur jego aktualizowania i dokonywania innych zmian planu niż aktualizacja. Wszelkie zmiany w obrębie planów zarządzania kryzysowego akty normatywne traktuja jako aktualizacje i nie wyróżniają żadnej innej formy jak choćby zmiany, modyfikacje, korekty czy poprawki.

Realne aktualizacje planu powinny być tworzone $\mathrm{w}$ oparciu o wnioski z zaistniałych zagrożeń i sytuacji kryzysowych oraz przeprowadzonych szkoleń i ćwiczeń. Jest to zabieg celowy i majacy wymierny wpływ na funkcjonalność planów zarządzania kryzysowego, w przeciwieństwie do korekty danych osobowych pracowników, która postrzegana jest jako spełnienie obowiąku aktualizacji planu. Wszystkie pozostałe kierunki zmian i doskonalenia systemu wiążą się ściśle $z$ finansami, przeznaczanymi na działalność administracji publicznej, służb wykonawczych, organizacji pozarządowych i edukację społeczeństwa. W oparciu o zaprezentowany w poprzednich rozdziałach stan faktyczny funkcjonowania zarzadzania kryzysowego, zasadnym posunięciem byłoby znaczne zwięk- 
szenie finansowania zadań zarządzania kryzysowego połączone $z$ realnym nadzorem nad jego wydatkowaniem i kontrola realizacji ustawowych powinności w celu uniknięcia rażacych zaniedbań nawet $\mathrm{w}$ sferze organizacyjnej, $\mathrm{z}$ jakimi mamy do czynienia obecnie.

Funkcjonowanie jednego Centrum Zarządzania Kryzysowego przy 10 osobowej obsadzie to koszt około $1 \mathrm{mln}$ złotych w skali roku. Utworzenie centrum w każdej gminie generuje konieczność przeznaczania na ten cel ogromnych środków finansowych, dlatego dobrym rozwiązaniem byłoby stworzenie centrów obsługujacych kilka gmin lub zapewnienie realnego dyżuru telefonicznego poza godzinami pracy gminnej komórki właściwej w sprawach zarządzania kryzysowego. Konieczne jest także zapewnienie stałej ogólnopolskiej łączności i awaryjnego zasilania, umożliwiającego komunikowanie się między sobą w sytuacjach kryzysowych organów administracji publicznej i służb ratunkowych. Rozbudowy wymaga również wojewódzki System Ostrzegania i Alarmowania Ludności, w celu objęcia swoim zasięgiem także samorządów. Ponadto za zarządzanie kryzysowe na szczeblu gminnym musi być odpowiedzialny przynajmniej jeden pracownik, nieobarczony innymi zadaniami zwiąanymi $z$ funkcjonowaniem urzędu. W przeciwnym razie zarządzanie kryzysowe na tym poziomie będzie tylko fikcją.

W aspekcie funkcjonowania służb niezbędne jest dostosowanie ich struktury organizacyjnej do właściwego reagowania na zdarzenia mnogie, masowe i katastrofy. Koncentracja sił i środków na danym obszarze powinna być w stanie zapewnić bezpieczeństwo mieszkańców w każdej $z$ wymienionych kategorii zdarzeń. Natomiast sprzęt powinien być rozlokowany w miejscach regularnego występowania zagrożeń, a nie w magazynach powiatowych. Mniejsza ilość wyposażenia, lecz na większym terenie umożliwi znacznie szybsze reagowanie i podejmowanie działań, zapobiegających eskalacji zagrożenia. Ważnym aspektem jest również rotacja sprzętu przestarzałego i zużytego, poszerzanie bazy logistycznej systemu w celu uzupełniania braków sprzętowych służb ratunkowych oraz dofinansowywanie szkoleń i ćwiczeń, pozwalających na lepsze współdziałanie podmiotów wykonawczych i koordynacyjnych. Dobrym rozwiazaniem angażujacym komponent społeczny byłoby stworzenie aplikacji przeznaczonej do informowania o lokalnych zdarzeniach. Przy obecnych rozwiązaniach telekomunikacyjnych 
i technologicznych można stworzyć doskonałe źródło powiadamiania lokalnej ludności o zagrożeniach, np. wypadkach komunikacyjnych, kolejowych czy złych warunkach atmosferycznych. Zgłoszenie zagrożenia powinno wiązać się ze wskazaniem tras alternatywnych, podaniem opóźnień w komunikacji oraz wskazaniem środków komunikacji zastępczej.

\section{Bibliografia / References}

Dane pozyskane $\mathrm{w}$ trakcie wywiadów przeprowadzonych $\mathrm{z}$ dowódcami właściwych jednostek organizacyjnych Państwowej Straży Pożarnej, Policji, Wojskowej Komendy Uzupełnień w Siedlcach, w grudniu 2018.

Gromek P., W sieci ratownictwa, Warszawa 2018.

Kalinowski R., Od gotowości cywilnej do zarzadzania kryzysowego, „Przegląd Naukowo-Metodyczny. Edukacja dla Bezpieczeństwa” 2013, nr 4.

Kalinowski R., Wybrane problemy zarzadzania kryzysowego na szczeblu województwa. Wstępne refleksje z badań, [w:] Elementy teorii i praktyki transdyscyplinarnych badań problemów bezpieczeństwa, T. III Psychospoleczne $i$ organizacyjne aspekty zarzadzania kryzysowego, red. A.W. Swiderski, Siedlce 2014.

Kopczewski M., Tobolski M., Funkcjonowanie Krajowego Systemu Ratowniczo-Gaśniczego istotnym elementem Systemu Zarzadzania Kryzysowego Państwa, [w:] Zarzadzanie kryzysowe $w$ systemie bezpieczeństwa narodowego, red. G. Sobolewski, D. Majchrzak, Warszawa 2001.

Król A., Biernat A., Pożar lasu w Kuźni Raciborskiej: Piekło sprzed 25 lat. Opowieści ludzi, którzy walczyli $z$ ogniem, www.plus. dziennikzachodni.pl/pozar-lasu-w-kuzni-raciborskiej-pieklo-sprzed-25-lat-opowiesci-ludzi-ktorzy-walczyli-z-ogniem/ar/12396097 (data dostępu: 31.12.2020).

Mazowiecki Urząd Wojewódzki w Warszawie, Plan działania systemu PRM, www.gov.pl/web/uw-mazowiecki/plan-dzialania-systemu-prm (data dostępu: 31.12.2020).

Najwyższa Izba Kontroli, Informacja o wynikach kontroli Ochrona ludności $w$ ramach zarzadzania kryzysowego $i$ obrony cywilnej, Warszawa 2019, KPB.430.009.2017, Nr ewid. 147/2018/P/1039/KPB.

Plan działania systemu Państwowe Ratownictwo Medyczne dla województwa mazowieckiego, Tekst jednolity, Warszawa 18.12.2020 r.

Projekt ustawy o ochronie ludności i obronie cywilnej, www.legislacja.rcl. gov.pl/projekt/12322353 (data dostępu: 31.12.2020).

Rozbudowa systemu alarmowania $i$ ostrzegania ludności $w$ Warszawie, www.europa.um.warszawa.pl/projekty-miejskie/rozbudowa-systemualarmowania-i-ostrzegania-ludno-ci-w-warszawie (data dostępu: 31.12.2020). 
Rozporządzenie Rady Ministrów z dnia 29 stycznia 1937 roku o przygotowaniu w czasie pokoju obrony przeciwlotniczej i przeciwgazowej Państwa, Dz. U. 1937, nr 10, poz. 73.

Rządowy projekt ustawy o zmianie ustawy o zarządzaniu kryzysowym oraz niektórych innych ustaw, www.sejm.gov.pl/Sejm9.nsf/PrzebiegProc. xsp?nr=203 (data dostępu: 31.12.2020).

Szmitkowski P., System ochrony ludności $w$ Polsce - historia $i$ współczesność, „Colloquium Wydziału Nauk Humanistycznych i Społecznych” 2012 , nr 4.

Ustawa $z$ dnia 15 marca 1934 r. o obronie przeciwlotniczej i przeciwgazowej, Dz.U. 1934, nr 80, poz. 742.

Ustawa z dnia 26 kwietnia 2007 r. o zarządzaniu kryzysowym, Dz.U. 2007, nr 89, poz. 590 .

Ustawa z dnia 8 września 2006 r. o Państwowym Ratownictwie Medycznym, Dz. U. 2006, nr 191, poz. 1410. 
